\title{
CATTLE PRODUCERS' WILLINGNESS TO ADOPT OR EXPAND PRESCRIBED GRAZING IN THE UNITED STATES
}

\author{
KIMBERLY L. JENSEN* \\ Department of Agricultural and Resource Economics, University of Tennessee, Knoxville, Tennessee \\ DAYTON M. LAMBERT \\ Department of Agricultural and Resource Economics, University of Tennessee, Knoxville, Tennessee \\ CHRISTOPHER D. CLARK \\ Department of Agricultural and Resource Economics, University of Tennessee, Knoxville, Tennessee \\ CAROLINE HOLT \\ Tennessee Valley Authority, Knoxville, Tennessee \\ BURTON C. ENGLISH \\ Department of Agricultural and Resource Economics, University of Tennessee, Knoxville, Tennessee
}

JAMES A. LARSON

Department of Agricultural and Resource Economics, University of Tennessee, Knoxville, Tennessee

T. EDWARD YU

Department of Agricultural and Resource Economics, University of Tennessee, Knoxville, Tennessee

CHAD HELLWINCKEL

Department of Agricultural and Resource Economics, University of Tennessee, Knoxville, Tennessee

\begin{abstract}
A triple hurdle model estimates cattle farmer willingness to adopt or expand prescribed grazing on pasture in the United States in response to a hypothetical incentive program. Interest in adoption/expansion is estimated first, then willingness to participate in the program, followed by intensity of participation measured as additional acres enrolled. The supply elasticity of enrolled acres with respect to the incentive is 0.13 . Nonpecuniary factors inter alia farmer sentiment about stewardship, current farm management practices, farm location, and education are associated with farmer willingness to participate and with participation intensity.
\end{abstract}

Keywords. adoption, prescribed grazing, triple hurdle model

JEL Classifications. Q18, Q12

This project was supported by Agriculture and Food Research Initiative Competitive Grant No. 10642663 from the U.S. Department of Agriculture, National Institute of Food and Agriculture.

*E-mail: kjensen@utk.edu 


\section{Introduction}

Enteric fermentation from ruminants contributes approximately $2.2 \%$ of all U.S. greenhouse gas (GHG) emissions, with $96 \%$ of this coming from beef and dairy cattle (U.S. Environmental Protection Agency [EPA], 2014b). Thus, reducing GHG emissions from beef cattle production could lower total U.S. GHG emissions. The U.S. Department of Agriculture, Natural Resources Conservation Service (USDA/NRCS) defines prescribed grazing as the "controlled harvest of vegetation with grazing animals, managed with the intent to achieve a specific objective" (USDA/NRCS, 2010b, p. 1). The NRCS practice code 528-prescribed grazing-is a best management practice (BMP) that reduces GHG emissions from cattle grazing by increasing the amount of carbon sequestered on pastureland. In addition, prescribed grazing can improve species composition and vigor of plant communities, improve water quality, benefit riparian and watershed function, and reduce soil erosion and improve soil condition (USDA/NRCS, 2010b). Beyond these environmental benefits, farmers may benefit from more and better quality forage, allowing higher stocking rates. Comparing the feed value of intensive grazing with that from all hay or all corn silage, intensive grazing may be more profitable than hay and corn silage enterprises (Hanson, 1995).

The NRCS encourages producers to choose from five grazing plans ranging from "Basic" to "High Intensity Rotational Feeding." Each plan requires that cattle graze in paddocks, but the number of paddocks, stocking density, and grazing rotation frequency vary. For the Basic plan, producers are required to manage four to five paddock rotations per herd, with three or more paddocks recovering at any one time from April to October. At the other extreme, producers can choose the High Intensity Rotational Feeding option, which requires five or more paddocks per herd, with five or more paddocks recovering at any one time all year and half-acre pasture stockpiles reserved per animal unit and cattle feeding sites rotated between paddocks. For all pasture management plans, producers must develop an approved conservation plan with a grazing component, document management practices annually, balance forage with $<33 \%$ feed, and maintain minimum grazing heights.

By managing vegetation harvest, plants grow longer during the grazing season producing higher quality forage and increased forage production. Increased forage quantities can also augment carbon storage in soils, in turn offsetting GHG emissions associated with livestock production (Briske et al., 2013). Methane emissions from cattle produced in a prescribed grazing system may also be lower than from cattle fed on conventional pasture systems (Cottle, Nolan, and Wiedermann, 2011). ${ }^{1}$ Prescribed grazing may also improve soil fertility

1 Estimated carbon $(\mathrm{C})$ sequestration rates for grazing management practices have been estimated at 0.30 to 1.30 metric tons (MT)/acre (Follet et al., 2001). 
and reduce the adverse impacts of grazing on water quality (Powell, 1998; Thomas, 2002; USDA/NRCS, 2007). Prescribed grazing provides private benefits to producers, including increases in pastureland carrying capacity, robust forage growth, forage species diversity, more efficient forage use, and lower rates of soil erosion (Undersander et al., 2002).

The perceived and tangible benefits producers gain from adopting BMPs may not always counterbalance the financial and time value costs of adoption (Lichtenberg and Smith-Ramírez, 2011). Prescribed grazing systems entail start-up costs and increased managerial effort. Uncertainty about costs, time commitment, and planning horizon can also reduce interest in BMPs (Kim, Gillespie, and Paudel, 2008). The Environmental Quality Incentives Program (EQIP) provides producers incentives of $50 \%$ to $75 \%$ of the costs of installing structures or annually implementing management practices to adopt prescribed grazing. However, EQIP and other programs designed to promote BMP adoption are voluntary, and their effectiveness is contingent on producer willingness to adopt BMPs, producer willingness to participate in cost-share programs, and producer resolve to implement practices stipulated by the cost-share program. Farmers initiating prescribed grazing may incur seeding costs, fencing costs, installation of water-use facilities in paddocks, and placement of protection in heavy-use areas. Continuing prescribed grazing over time may entail maintenance of fencing, replanting grass, planning fertilizer and herbicide use, replacing heavy-use area geotextiles, pasture clipping, soil testing, and labor to oversee the practice (USDA/NRCS, 2013a). The 2012 NRCS estimate of land on which EQIP practice code 528 is implemented as a conservation practice was just over 6.6 million acres (USDA/NRCS, 2013a). ${ }^{2}$

This study uses results from a 2013 survey of U.S. cattle producers to examine the factors influencing producer willingness to adopt or expand prescribed grazing on beef cattle farms east of the 100th meridian, including the effects of a hypothetical incentive program (Figure 1). The hypothetical program is based on many of the NRCS practice 528 parameters including the structures and management practices used by NRCS to define prescribed grazing. The hypothetical program examined here offers a $75 \%$ cost share for installation costs along with an annual per acre payment for 10 years to encourage continued use of prescribed grazing. The amount of the annual payment is randomized over respondents to estimate the effect of incentive levels on program recruitment and participation intensity. Other factors hypothesized to influence willingness to adopt or expand prescribed grazing include farm operator characteristics and farm structure and management practices. Understanding the producer and farm characteristics affecting BMP adoption/expansion, as well as the role of incentives on voluntary participation, could facilitate projections of the programmatic

2 According to the 2012 Census of Agriculture, the United States has a total of 415.3 million acres of permanent pasture and rangeland (USDA, 2014). 


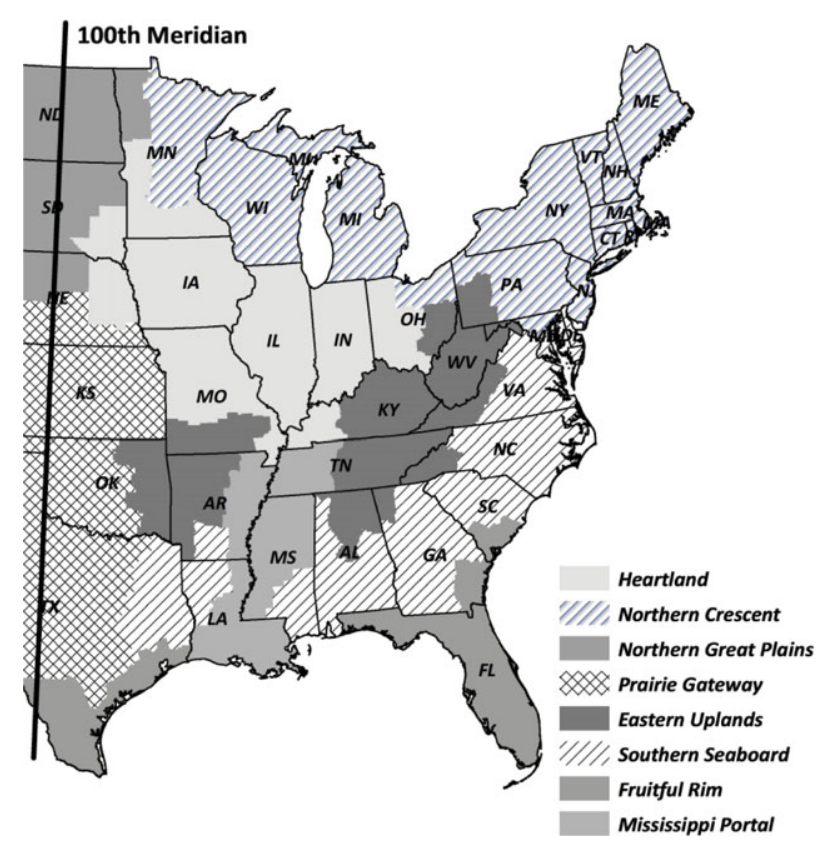

Figure 1. Area Surveyed East of the 100th Meridian

expenditures needed to obtain desired levels of acreage conversion to prescribed grazing or to reach specific environmental targets, such as specified reductions in GHG emissions associated with beef cattle production.

\section{Previous Research on Best Management Practice Adoption}

The BMP adoption literature analyzes the effects of incentive rates and a variety of other nonpecuniary factors on the voluntary adoption of structures or practices designed to mitigate the environmental impacts of agriculture. Cooper (1997) concluded that participation rates in cost-share programs were relatively unresponsive (e.g., inelastic) to changes in incentive levels. Lichtenberg (2004) found that row crop producers were cost responsive to incentives and preferred to adopt BMP practices in bundles. Lichtenberg and Smith-Ramírez (2011) found that incentives may induce higher participation rates but may have little or no effect on "participation intensity" or the extent of BMP provision given voluntary program participation.

Cooper and Signorello (2008) analyzed premiums encouraging the voluntary adoption of conservation plans. They examined what proportion of the willingness to adopt amount could be attributed to risk premiums. Their finding was that risk premiums accounted for approximately $36 \%$ of the mean willingness to accept value. Kurkalova, Kling, and Zhao (2006) estimated the 
financial incentives required for adopting conservation tillage, distinguishing between the expected payoff and adoption premium based on the observed behavior of Iowa farmers. Some nonadopters did not use conservation tillage because the expected profit gain alone did not compensate for the increased risk and possibility of irreversible lost profits associated with conventional tillage practices. Kurkalova, Kling, and Zhao also found that if a uniform conservation tillage adoption subsidy was offered, then approximately $86 \%$ of the program payments would have been income transfers to existing, low-cost adopters.

Rolfe et al. (2006) examined the effects of payment levels on adoption of selected measures of improvements in grazing practices (buffer strip width and forage biomass). Results from their study suggested that respondents were more likely to select alternatives with higher payment levels and less likely to select alternatives with extended buffer widths or minimum biomass conditions.

Foltz and Lang (2005) found that education and owned acres operated positively influenced the likelihood of adopting rotational grazing by Connecticut dairy farmers. Jayasinghe-Mudalige and Weersink (2004) found that the number of environmental management systems adopted by Canadian farmers, including rotational grazing for livestock, was positively influenced by farm profitability, farm size, and land ownership, but inversely related with age. Farms with mixed crop and livestock systems had the highest adoption rates, whereas livestock-only operations had the lowest.

Kim, Gillespie, and Paudel (2008) examined the effects of cost-share levels and farmer demographic variables on the willingness to adopt rotational grazing by Louisiana cattle producers. Cost-share levels positively influenced willingness to adopt. Their results also suggest that the probability of adoption could decline by as much as $0.85 \%$ for each percentage increased of the cost-share burden. Use of any rotational grazing type, higher debt to asset ratio, and plans for family members to take over the farm positively influenced adoption.

Prescribed grazing has potential drawbacks. For some producers, the initial investment costs and increased labor and management time may be too high (Gillespie et al., 2008). The profitability of prescribed grazing will vary across the large geographic area studied here due to differences in climate, land quality, and forages grown. Not all forage crops have the same response to rotational grazing. In some cases, prescribed grazing may not improve forage growth. Briske et al. (2008) found that multipaddock grazing does not significantly increase vegetation or animal production over continuous stocking practices.

This study builds on the findings from previous research, encompassing a much wider geographic area (east of the 100th meridian) than is typically investigated. The area east of the 100th meridian encompasses the region of the United States where the majority of pastureland rather than rangeland is located. The study results include estimates of the effects of per acre incentive payments on program participation and also on acres enrolled into a hypothetical prescribed grazing program. Interest in adoption or expansion and willingness to participate in a 
cost-share program to add prescribed grazing acreage are conditioned on relevant demographic and attitudinal factors.

\section{Survey Data}

The survey conducted for this study used a random sample of beef cattle, cow/calf, and backgrounding/stocker operations from the eight USDA Economic Research Service (USDA/ERS, 2000) regions east of the 100th meridian (Figure 1). The survey is available at http://beag.ag.utk. edu/pub/GrazingSurvey.pdf. The ERS regions are based on commodity production, geographic specialization, and other geographic characteristics. The stratified sample was drawn by USDA's National Agricultural Statistics Service (NASS) and was limited to operations with at least 20 head of cattle as reported by the 2007 Census of Agriculture to decrease the likelihood of sampling hobby farms. Strata were based on ERS production regions (Heartland, Northern Crescent, Northern Great Plains, Prairie Gateway, Eastern Uplands, Southern Seaboard, Fruitful Rim, and Mississippi Portal) and farm sales classes (<\$10,000; \$10,000-\$29,999; \$30,000-\$49,999; \$50,000-\$99,999; \$100,000-\$149,999; \$150,000-\$199,999; \$200,000-\$499,999; > \$500,000). A total of 8,875 operations were randomly selected from the population of 267,413 producers. The survey sample represented $3 \%$ of the total beef cattle farm population in the surveyed region. Sampling intensity and design were based on a $3 \%$ margin of error and a $95 \%$ confidence interval. Poststratification weights, used to weight the data in this analysis, were developed based on the cross tabulation of farm sales classes and ERS regions (Lambert et al., 2014). The procedure adjusts survey sample means toward expected population means based on two criteria: (1) the cell frequencies of respondents in given sales class and farm production regions, and (2) the cell frequencies based on USDA/NASS estimates along the same cell dimensions. The survey weights proportionally adjust the central tendencies of the survey sample to the expected frequency distribution of the farm population according to survey region and farm sales classes. The original procedure was first used by the U.S. Census of 1940 (Lohr, 1999). The mail survey was fielded by USDA/NASS in early 2013 with an initial mailing, a reminder postcard ( 1 week later), and second follow-up mailing (2 weeks after the reminder postcard). A total of 2,258 completed surveys were returned for a $26 \%$ response rate.

The survey instrument included three sections. The first section contained questions about the characteristics of the respondent's farming operation. The next section informed respondents about what prescribed grazing is and the on-site and off-site benefits of prescribed grazing systems (Figure 2). The second section also provided details about the management practices defining prescribed grazing (Figure 3). USDA/NRCS technical guidance was used as the basis for the prescribed grazing specifications (USDA/NRCS, 2007). The prescribed grazing 
What is prescribed grazing?

- Prescribed grazing is the controlled harvest of vegetation by grazing animals.

- Controlled harvest means managing the duration, intensity, distribution, frequency, and season animals graze on a pasture.

- Management practices include:

- Rotating cattle around a number of paddocks (fenced fields) in an ordered sequence;

- Monitoring forage stubble height for the best grazing start and stop times; and

- Removing cattle from grazing areas to allow forage recovery.

How would prescribed grazing benefit you?

- Grow more and better quality forage;

- Allow higher stocking rates (estimates are up to $40 \%$ increases); and

- Increase use of forage from pastures.

How would prescribed grazing affect the environment?

- Increased yields and efficiency per unit of land means less pollution; and

- Concentrating livestock in paddocks for days at a time lets animals graze lightly but evenly, encouraging roots to grow deeper into the soil, storing more organic matter (carbon).

Figure 2. Survey Description of Prescribed Grazing and Potential Benefits

What would you need to do to practice prescribed grazing?

Manage forage by:

- Balancing livestock consumption and forage production;

- Adjusting livestock numbers, fertilizer rates, or purchased feed to meet livestock forage needs;

- Limiting feed (hay, silage, gluten, hulls, grain, etc.) to no more than $50 \%$ of total livestock diet; and

- Creating a weed control plan and controlling weeds in pastures by clipping, spraying, high-density grazing, mixed species grazing, and/or weed wiping as needed.

Rotate livestock by:

- Using at least five different paddocks or fields for grazing;

- Grazing livestock for no more than 14 continuous days on any paddock or field (except during extreme weather conditions);

- Buffering sensitive areas like wells, depressions, sinkholes, and all water areas in paddocks;

- Developing a conservation plan that includes a grazing component with a technical consultant; and

- Not grazing more than $20 \%$ of the pasture to less than minimum grazing heights of:

- 2" for Bermuda grass, ryegrass;

- 3" for cool season grasses (e.g., tall fescue, orchard grass, cereal grains); and

- 6" for tall upright grasses (e.g., native grass, millet, sorghums).

Record keeping:

- Keep records to show continued use of prescribed grazing practices.

(Source: USDA/NRCS, 2007)

Figure 3. Survey Description of Management Practices Used in Prescribed Grazing

information was followed by questions asking respondents if they used any practices identified with prescribed grazing in the previous year and, if so, which ones. If respondents used some of the management practices, they were asked if they had received government payments for these practices through federal programs such as EQIP.

Respondents were provided with installation cost estimates. Installation cost estimates were based on existing cost estimates from program payment structures 


\begin{tabular}{lcccc}
\hline Region & $\begin{array}{c}\text { Prescribed } \\
\text { Grazing } \\
(\$ / \text { Acre })\end{array}$ & $\begin{array}{c}\text { Fence } \\
(\$ / \text { Strand Foot })\end{array}$ & $\begin{array}{c}\text { Watering } \\
\text { Facility } \\
(\$ / \text { Gallon })\end{array}$ & $\begin{array}{c}\text { Heavy-Use } \\
\text { Areas } \\
\text { (\$/Square Foot) }\end{array}$ \\
\hline Northeast & 34.86 & 1.86 & 2.34 & 1.76 \\
Lake States & 36.09 & 1.34 & 1.31 & 1.16 \\
Corn Belt & 23.38 & 1.12 & 1.8 & 1.21 \\
Northern Plains & 24.96 & 1.36 & 1.72 & 1.72 \\
Appalachia & 31.07 & 1.49 & 2.43 & 1.18 \\
Southeast & 21.35 & 1.09 & 1.14 & 1.23 \\
Delta & 48.26 & 1.42 & 0.61 & 1.20 \\
Southern Plains & 28.82 & 1.38 & 1.72 & 1.35 \\
\hline
\end{tabular}

${ }^{a}$ Northeast: CT, DE, ME, MD, MA, NH, NJ, NY, PA; Lake States: MN, WI, MI; Corn Belt: IL, IN, IA, MO, OH; Northern Plains: KS, NE, ND, SD; Appalachia: KY, NC, TN, VA, WV; Southeast: AL, FL, GA, SC; Delta: AR, LA, MS; Southern Plains: OK, TX.

(Source: Based on USDA/NRCS, 2013b)

Figure 4. Estimated Regional Costs of Prescribed Grazing

(EQIP) and aggregated to the USDA farm commodity production regions (Figure 4; USDA/NRCS, 2013b).

Respondents were also provided cost estimates for additional components needed for prescribed grazing (i.e., installing temporary or permanent fencing, providing watering facilities in each paddock, and providing heavy-use protection), as shown in Figure 4. Respondents were then asked to indicate which of the following best describes whether they would adopt or expand prescribed grazing:

1. I would not adopt or expand prescribed grazing even if it was profitable to do so.

2. I would adopt or expand prescribed grazing even if it was not profitable to do so.

3. I would adopt prescribed grazing only if it was profitable to do so.

Respondents who chose (1) were considered nonadopters/nonexpanders, whereas those who choose (2) or (3) were categorized as adopters/expanders.

Adopters/expanders were then informed of a hypothetical program offering an incentive composed of a $75 \%$ structure installation cost share and annual payments for 10 years to either expand the number of acres managed with prescribed grazing (for respondents already using these management practices and receiving government payments) or manage a portion of their farm area using a prescribed grazing system (for respondents not currently using prescribed 
We now ask you about a HYPOTHETICAL PROGRAM to encourage farmers and ranchers to adopt or expand prescribed grazing. Assume the program would:

- Pay $75 \%$ of the costs of purchasing and installing the components needed to adopt or expand prescribed grazing on your farm or ranch;

- Pay you continuing annual payments for 10 years if you follow all of the practices described on page 4 and document these practices each season;

- Not limit the number of acres you can enroll; and

- Be limited to acres not enrolled in another conservation program.

Would you be willing to convert pasture acres on your farm to prescribed grazing for a 10 -year period if you were offered (a) the $75 \%$ installation cost share described above and (b) an ANNUAL payment of [\$10, $\$ 20, \$ 50, \$ 70$, or $\$ 90]$ per acre for each of the 10 years you practice prescribed grazing?

Yes, I would adopt or expand prescribed grazing.

No, I would not adopt or expand prescribed grazing.

Figure 5. Program Description and Participation Question

grazing systems; Figure 5). ${ }^{3,4}$ Note that respondents were provided with a description and cost estimates (Figures 2, 3, and 4) prior to being asked about their responsiveness to the hypothetical incentive program. Respondents indicating willingness to accept the incentive and participate in the program were then asked how many acres they would enroll in the program and convert to prescribed grazing. Enrollment in the program could represent either adoption by farmers not currently using prescribed grazing or expansion onto additional acres by those already using prescribed grazing. Five versions of the survey were randomly distributed across the survey sample. Each version differed only in the amount of the hypothetical incentive offered to enroll pasture acres into the prescribed grazing program. The incentive levels were $\$ 10, \$ 30, \$ 50, \$ 70$, and $\$ 90$ per acre per year over a 10 -year horizon. These levels were based on the results of a pilot survey conducted before the primary survey. The final section of the survey included questions about respondent characteristics, including operator age, income, household size, farming experience, and education. After eliminating incomplete records, there were 1,153 observations available for analysis. Expanding this sample by the survey weights results in a projected 145,723 farms.

\section{Conceptual Model}

The survey design compels three levels of analysis: (1) willingness to adopt or expand prescribed grazing (absent an incentive); (2) willingness to participate in

3 Respondents who were not interested in adopting or expanding prescribed grazing even if it was profitable to do so were instructed to skip the questions pertaining to the hypothetical incentive program.

4 NRCS analysis has shown that the average practice life for the grazing improvement practices was 11.6 years, with nearly full benefits occurring in years 2 through 7 , followed by a gradual taper to $70 \%$ of benefits in year 10. For prescribed grazing, the practice life was assumed at 5 years, but with the annual benefits from the practice occurring through year 9 (USDA/NRCS, 2010a). 
the hypothetical incentive program, given interest in adopting or expanding prescribed grazing; and (3) participation intensity (acres enrolled, given acceptance of the incentive).

\subsection{Adoption/Expansion of Prescribed Grazing}

Cattle farmers maximize the stream of returns from livestock production less variable costs by choosing optimal feeding and animal replacement schedules. Producers make decisions about stocking density and pasture maintenance, with weather, plant growth, and plant-growth/animal interactions typically beyond the producer's control (Kennedy, 1985). In addition to this management decision dynamic, producers may voluntarily participate in a prescribed grazing program that could reduce production risk or increase profits by enhancing pasture productivity.

In the absence of an incentive, adoption or expansion of a BMP is hypothesized to occur when the producer's utility $(u)$ from adopting or expanding $(A)$ the practice is at least as great as the producer's utility without adoption or expansion of the practice. In other words, a producer adopts or expands use of a BMP when $u_{A}(1, I ; x) \geq u_{A}(0, I ; x)$, where 0 denotes lack of adoption or expansion of the $\mathrm{BMP}$, and 1 adoption or expansion; $I$ is income; and $x$ is a vector of operator characteristics and farm attributes affecting the decision to adopt or expand the practice.

McFadden's (1974) random utility model is commonly applied in the technology adoption literature to explain the systematic (observable) component of utility as a function of the measurable covariates, $x$. For example,

$$
u_{A}^{j}=x \beta^{j}+\varepsilon_{A}^{j},
$$

where $j=0,1$ is the state of adoption or expansion; $x \beta^{j}$ is the observable, systematic component of utility; and $\varepsilon_{A}^{j}$ is an unobservable, independent, and identically distributed disturbance. Producers adopt or expand use of the BMP when the latent variable $\bar{u}_{A}=u_{A}^{1}-u_{A}^{0}$ is positive. The likelihood of adopting or expanding the BMP is extended to a probabilistic framework, namely

$$
\operatorname{Pr}(j=1)=\operatorname{Pr}\left(x \beta_{A}^{0}+\varepsilon_{A}^{0} \leq x \beta_{A}^{1}+\varepsilon_{A}^{1}\right)=\operatorname{Pr}\left(\varepsilon_{A}^{0}-\varepsilon_{A}^{1} \leq x \beta\right)
$$

after the typical normalization $\beta=\beta^{1}-\beta^{0}$. The probability of adopting or expanding use of the technology is $\operatorname{Pr}(j=1)=F_{\varepsilon A}(x \beta)$, where $F_{\varepsilon A}$ is a cumulative distribution function of $\varepsilon_{A}$.

\subsection{Program Participation}

Producers considering participation in a program subsidizing BMP adoption or expansion with an incentive may employ a slightly different reasoning. A producer is willing to participate in the program when the expected utility of adopting or expanding and participating exceeds the utility of not doing so, or when $u\left(1, I+B ; x, \varepsilon_{A}\right) \geq u\left(0, I ; x, \varepsilon_{A}\right)$, where 0 denotes failure to participate 
and 1 is participation; $B$ is an incentive; and $I$ and $x$ are previously defined. Unobserved factors determining the adoption or expansion decision may be correlated with the participation decision. Following Cooper (1997), B can be thought of as a net program incentive, where any extra costs associated with program participation beyond the costs of adopting or expanding the practice, such as the costs of documenting compliance with program requirements, are deducted from the amount of the incentive paid to producers.

In practice, the producer's utility function is unknown because some components are unobserved. From the researcher's perspective, utility is observed as a systematic and random component, with

$$
v\left(j, I+j B ; x, \varepsilon_{A}\right)
$$

the mean of utility in state $j$, and $v()$ is an indirect utility function. Including an independent and identically distributed stochastic component, $\varepsilon^{j}$ denotes the incomplete observability of utility. Provided these assumptions, producer willingness to participate in the program, given the net incentive $B$, is

$$
v\left(1, I+B ; x, \varepsilon_{A}\right)+\varepsilon^{1} \geq v\left(0, I ; x, \varepsilon_{A}\right)+\varepsilon^{0} .
$$

The dichotomous choice contingent valuation literature commonly parameterizes the indirect utility function as an argument linear in terms,

$$
v\left(j, I+j B ; x, \varepsilon_{A}\right)=\gamma_{0}^{j}+\gamma_{1} I,
$$

with $\gamma_{1}$ strictly positive. Producers participate (i.e., accept $B$ ) to voluntarily change their practices when $\gamma_{0}^{0}+\gamma_{1} \cdot I+\varepsilon^{0} \leq \gamma_{0}^{1}+\gamma_{1} \cdot(I+B)+\varepsilon^{1}$. The likelihood that a producer participates in the program is extended to a probabilistic framework, namely

$$
\operatorname{Pr}(P A R T I C I P A T E \leq B)=\operatorname{Pr}\left(v^{0}+\varepsilon^{0} \leq v^{1}+\varepsilon^{1}\right)=\operatorname{Pr}\left(\varepsilon^{0}-\varepsilon^{1} \leq \gamma_{0}+\gamma_{1} B\right)
$$

after the normalization $\gamma_{0}=\gamma_{0}^{1}-\gamma_{0}^{0}$. Other covariates $(x)$ may systematically influence program participation. In this case, the probability of participating, given incentive payment $B$, is

$$
\operatorname{Pr}(P A R T I C I P A T E \leq B)=F_{\varepsilon}\left(\gamma_{0}+\gamma_{1} \cdot B+x \cdot \gamma\right),
$$

where $F_{\varepsilon}$ is a cumulative distribution function of the error term $\varepsilon$.

\subsection{Participation Intensity}

Producers accepting the offer payment also decide at what level of intensity to participate. Similar to the solution characterizing the maximization of an indirect profit function (or minimization of an indirect cost function), the area enrolled into a prescribed grazing program is a function of the incentive level offered.

Another important determinant of the acres enrolled into any prescribed grazing program is the total available acres that decision makers have to offer 
in return for the payment. We assume that any such scale effects influencing the program acres supply function are fixed in the short term but influence the amount of acres that could be enrolled into the program. Pasture acres enrolled into a program are only observed among the set of producers accepting the offer, suggesting a censoring mechanism.

\section{Empirical Model and Estimation}

Acres enrolled in the hypothetical prescribed grazing program are modeled as a sequence of decisions beginning with willingness to adopt or expand prescribed grazing $(A D O P T)$; willingness to participate in the hypothetical prescribed grazing program, given the cost share and annual payment offered (PARTICIPATE); and the number of acres the respondent is willing to enroll in the program $(A C R E S)$, given the incentive offered. A triple hurdle regression models this decision sequence as a tiered series of latent variables.

$$
\begin{aligned}
& A D O P T_{i}^{*}=\beta^{\prime} X_{1 i}+\varepsilon_{A i} \\
& A D O P T_{i}= \begin{cases}1, & A D O P T_{i}^{*}>0 \\
0, & A D O P T_{i}^{*} \leq 0\end{cases} \\
& \text { PARTICIPATE }{ }_{i}^{*}=\gamma^{\prime} X_{2 i}+\varepsilon_{i}
\end{aligned}
$$

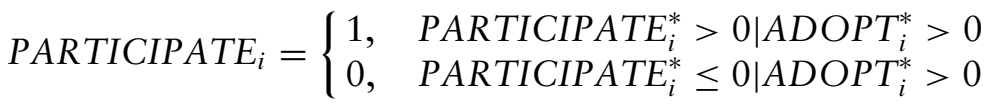

$$
\begin{aligned}
& \ln \operatorname{ACRES}_{i}^{*}=\eta^{\prime} X_{3 i}+e_{i} \\
& \ln \text { ACRES }_{i}=\left\{\begin{array}{cc}
\ln \text { ACRES }_{i}^{*}, & \text { PARTICIPATE } \\
-, & \text { PARTICIPATE }
\end{array}\right.
\end{aligned}
$$

In the first hurdle (equation 8), producers were asked if they would adopt or expand prescribed grazing following a description of the practice and an estimate of prescribed grazing costs. This first hurdle separates the participation decision from the consumption or level of expenditure decision (Blaylock and Blisard, 1992; Qualls et al., 2012; Yen, 2005). Applied researchers often use this type of screening question in surveys with choice experiments to determine whether respondents really "belong to" a particular market or not, to reduce the burden on respondents, and to minimize yea-saying (Blamey, Bennett, and Morrison, 1999). For example, a certain portion of individuals will not smoke or drink no matter how cheap cigarettes or alcohol are; these individuals do not belong to these markets. Asking this type of screening question allows researchers 
investigating willingness to pay (WTP) for cigarettes or alcohol to distinguish these individuals (i.e., those for whom WTP is equal to zero) from those whose reservation price has not been met. One might argue that this logic does not hold in a willingness-to-adopt study, as a large enough subsidy would likely induce all or almost all producers to participate. However, inducing participation in the hypothetical program among individuals who would be unwilling to expend the resources necessary to learn about a real program has the potential to introduce its own form of bias. In this analysis, producers who answered "no" to ADOPT are considered in the overall probability estimates of the ADOPT model but do not contribute to the incentive response part of the acreage supply model. In these cases, accounting for the individuals self-selecting out of the willingnessto-adopt exercise is important to minimize willingness-to-adopt estimate bias arising from sample selection. This is accomplished by estimating the first tier of the model (equation 8) jointly with participation (equation 9) and participation intensity (equation 10).

In the second hurdle (equation 9), producers who were willing to adopt or expand prescribed grazing $(A D O P T=1)$ were offered an up-front cost share and a per acre annual payment for enrolling pasture acres into the hypothetical program. Producers either refused (PARTICIPATE $=0)$ or accepted the offer (PARTICIPATE $=1$ ). The outcome equation (equation 10) models the acres supplied by producers given their willingness to adopt or expand prescribed grazing and participate in the incentive program (i.e., ADOPT = 1 and PARTICIPATE = 1). The natural logarithm of the acres enrolled is used to ensure that enrolled acreage predictions are positive because enrolled acres reported are strictly greater than zero.

The error terms of equations (8)-(10) are correlated and assumed to be multivariate normally distributed each with an expected value of zero:

$$
\left[\begin{array}{c}
\varepsilon_{A i} \\
\varepsilon_{i} \\
e_{i}
\end{array}\right] \sim \operatorname{MVN}\left(\left[\begin{array}{l}
0 \\
0 \\
0
\end{array}\right],\left[\begin{array}{ccc}
1 & \rho_{12} & \sigma \rho_{13} \\
\rho_{12} & 1 & \sigma \rho_{23} \\
\sigma \rho_{13} & \sigma \rho_{23} & \sigma^{2}
\end{array}\right]\right) .
$$

Given these assumptions, the parameter vectors $(\beta, \gamma, \eta)^{\prime}$ and the covariance matrix in equation (11) can be jointly estimated using full information maximum likelihood. The log likelihood function for the system is:

$$
\begin{aligned}
\ln L= & \sum_{A D O P T_{i}^{*} \leq 0} \ln \left[\Phi\left(-\beta^{\prime} X_{1 i}\right)\right] \\
& +\sum_{\substack{\text { ADOPTT } \\
\text { PARTICIPATE } \\
i} \leq 0}^{*} \ln \left[\Phi_{2}\left(\beta^{\prime} X_{1 i},-\gamma^{\prime} X_{2 i},-\rho_{12}\right)\right] \\
& +\sum_{\substack{\text { PARTICIPATE } \\
\text { ADOPT }}}^{*} \ln \left[h\left(\ln A C R E S_{i} \mid \beta^{\prime} X_{1 i}, \gamma^{\prime} X_{2 i}, \eta^{\prime} X_{3 i}, \rho_{12}, \rho_{13}, \rho_{23}, \sigma\right)\right] .
\end{aligned}
$$




\subsection{Marginal Effects}

The marginal effects of each outcome are calculated from the conditional and unconditional expected values of acres enrolled into the program. Extending Yen and Rosinski (2008) and Cameron and Trivedi's (2009) derivation to a bivariate normal selection sequence, the unconditional expected mean pasture acres enrolled are calculated as:

$$
E\left(\ln A C R E S_{i}\right)=\exp \left(\eta^{\prime} X_{3 i}+\frac{\sigma^{2}}{2}\right) \cdot \Phi_{2}\left(\beta^{\prime} X_{1 i}+\sigma \rho_{13}, \gamma^{\prime} X_{2 i}+\sigma \rho_{23}, \rho_{12}\right) .
$$

The conditional mean of acres enrolled into the program is calculated as:

$$
\begin{aligned}
& E\left(\ln A C R E S_{i} \mid A C R E S_{i}>0, A D O P T_{i}=1\right) \\
& \quad=\exp \left(\eta^{\prime} X_{3 i}+\frac{\sigma^{2}}{2}\right) \cdot \frac{\Phi_{2}\left(\beta^{\prime} X_{1 i}+\sigma \rho_{13}, \gamma^{\prime} X_{2 i}+\sigma \rho_{23}, \rho_{12}\right)}{\Phi_{2}\left(\beta^{\prime} X_{1 i}, \gamma^{\prime} X_{2 i}, \rho_{12}\right)} .
\end{aligned}
$$

The marginal effect equations (equations 13 and 14) are estimated using a finite difference approximation algorithm (Cameron and Trivedi, 2009). For the willingness to adopt and willingness to participate portions of the model, the marginal effects are derived from the numerator and denominator of the bivariate cumulative density ratio in the conditional mean expression. It is important to note that variables included in superior tiers indirectly influence the marginal effect calculations of dependent variables in lower tiers even if those variables do not directly enter the equation. For example, variables in $X_{1}$ and $X_{2}$ not included in $X_{3}$ indirectly affect acres enrolled through the derivative chain rule.

\section{Explanatory Variables}

The explanatory variables included in the ADOPT, PARTICIPATE, and ACRES equations are different for theoretical reasons and purposes of estimation. Linear identification of the decision sequence typically requires excluding variables in lower-tiered outcomes. In the absence of exclusion restrictions, the proposed model is identified only through nonlinear correlation between the error terms, which may introduce collinearity or cause solver nonconvergence.

It is also important to distinguish the interest in adoption or expansion of a BMP from participation in a program offering incentives with a specific set of requirements, and further still the intensity of adoption given participation in the hypothetical program. We assume that many of the variables included in the $A D O P T$ equation are irrelevant in the participation equation. Likewise, nonpecuniary variables included in the ADOPT and PARTICIPATE equations may not relate directly to the acreage enrollment decision (ACRES). For example, operator age will likely be negatively correlated with the adoption decisions. Less clear would be the influence of age on acreage enrollment, given that the producer already committed to voluntary participation. 


\subsection{Farm Operator Characteristics}

Farm operator age $(A G E)$ is typically negatively associated with technology adoption (Daberkow and McBride, 2003). Older farmers may be less willing to face learning curves or may have shorter planning horizons than younger farmers (Roberts et al., 2004). We expect that respondent age will be negatively associated with willingness to adopt or expand prescribed grazing. After this first hurdle, the relationship between $A G E$ and program participation and acres enrolled is less clear, and $A G E$ is not included in these models.

Education is typically hypothesized to be positively correlated with adoption or expansion (Walton et al., 2008). Farmers with higher levels of education may be better equipped to adopt more complex, integrated managerial practices requiring record keeping and coordinating stocking density, cattle growth, and forage growth cycles. We include a variable indicating whether the respondent had a college degree (COLLEGE) and hypothesize that it will be positively correlated with willingness to adopt or expand. The relationship between COLLEGE and participation and the acres enrolled is unintuitive, and COLLEGE is excluded from these models.

Perceptions about the role of farmers as land stewards (STEWARD) may influence respondent willingness to adopt prescribed grazing. Respondents who perceive that at least part of their role as farmers is as stewards of the land may recognize the off-site externalities caused by management practices maladapted to an agroenvironment or geography and, thus, be more likely to be willing to adopt or expand prescribed grazing. The role of self-assessed stewardship is less relevant to the participation and acreage enrollment sequences of the empirical models and is excluded.

The survey instrument was not designed to precisely measure risk aversion; yet risk premiums play an important role in the adoption decision-making process (Kurkalova, Kling, and Zhao, 2006). Respondents who indicated that they tended to wait to adopt agricultural technologies until others had adopted the technology (WADOPT) are hypothesized to be less willing to adopt or expand prescribed grazing. Because of the hurdle structure implied by the empirical model, the relationship between WADOPT and program participation and the acres enrolled is irrelevant and excluded from these models.

Individual perceptions about the role of government in decision making may influence respondent willingness to adopt and to participate in the incentive program. A dummy variable GOVINCENT was included in the $A D O P T$ and PARTICIPATE models, indicating that the respondent believed government should provide incentives to adopt conservation practices. The expected relationship between this variable and willingness to adopt or expand and to participate in an incentive-based program is positive (Lambert et al., 2007). The hurdle structure of the decision sequence precludes this variable from the acreage enrollment model. 
Expectations about the future of the farmstead postretirement may be an important determinant of technology adoption. As with other livestock BMPs, the investment required by prescribed grazing is tied to the land (Kim, Gillespie, and Paudel, 2008). It is expected that plans for family members to take over the operation after the respondent is no longer in charge will also have a positive effect on interest in the hypothetical program (FAMTKOV). This variable is hypothesized to be irrelevant in the program participation and acreage enrollment equations.

\subsection{Farm Structure}

Farm size is an important determinant of technology adoption. The larger the operation, the smaller the sunk costs of new technologies because costs are spread over more acres (Fernandez-Cornejo, Daberkow, and McBride, 2001). Larger operations may also control relatively more resources that can be retrofitted or adapted to accommodate novel production processes and new mechanical technologies. In the case of prescribed grazing, larger operations may already be familiar with rotational grazing between multiple paddocks and may be more likely to have the feeders and watering systems typically needed to enclose livestock. Owned acres farmed (ACFARM) measures the effect of farm size on willingness to adopt or expand prescribed grazing, willingness to participate in the incentive program, and acres enrolled in the program.

Farm ownership structure may influence the adoption decisions of farm managers (Lambert et al., 2007). We include a dummy variable in the willingness to adopt or expand model indicating farms that were operated as sole proprietorships (SOLE). This variable is excluded from the program participation and acreage enrollment models.

Household income is a proxy for the ability to invest in new technologies or practices (Walton et al., 2008). Household income may jointly (positively) influence willingness to adopt or expand prescribed grazing and also participate in an incentive-based program. Respondents reported annual household income in intervals $(\$ 30,000-\$ 49,000 ; \$ 50,000-\$ 99,000 ; \$ 100,000-\$ 149,000$; and $\$ 150,000$ or more). Dummy variables (INC3049K, INC5099K, INC100149K, and INCG150K) indicate the income intervals, with the lowest category omitted. The acreage enrollment model excludes these variables.

Cattle operations that also produce other livestock may be less interested in programs explicitly targeting the dual objectives of cattle production and forage management. Kim, Gillespie, and Paudel (2008) found that adoption of livestock BMPs was negatively associated with operation diversification, presumably because fewer resources could be allocated to the livestock enterprise. We include a dummy variable indicating if respondents produced other livestock (OTHLIV) in the ADOPT equation, but not the PARTICIPATE and ACRES models. 


\subsection{Farm Management Characteristics}

Recent studies of technology adoption suggest that producers using the Internet to find and update information about farm management and emerging technologies are more likely to adopt innovations (Watcharaanantapong et al., 2014). We include a dummy variable in the adoption/expansion equation, hypothesizing that producers who use the Internet to gather information to make farm management decisions (INTERNET) are more likely to adopt or expand prescribed grazing.

Respondents who network with other farmers and update their management practices through information provided by extension programs may be more likely to adopt technologies or integrate new practices into existing ones (Walton et al., 2010). Managerial ability may also increase following participation in extension workshops. A variable representing the number of extension workshops attended by the respondent during the previous year (EXTWK) was included in the ADOPT model, but not the program PARTICIPATE and ACRES equations.

Farmers managing relatively more of their land in pasture may be more likely to integrate prescribed grazing into their pasture management practices. A variable equal to the ratio of pastureland owned to total owned acres operated (SHRPAST) was included in the adoption/expansion model but excluded from the participation and acreage enrollment equations. This variable could serve as a proxy for fewer demands on farm resources, including the farmer's time, required to manage other land-intensive activities.

Farmers using resources to increase or sustain pasture fertility may recognize the soil-enhancing benefits typically associated with prescribed grazing routines. A dummy variable indicating if the respondent fertilized pastures to increase forage yield (FERTPAST) was included in the adoption/expansion model. The expected sign is positive.

Operations already managing pasture fertility using some or all of the prescribed grazing components analyzed are more likely to adopt or expand prescribed grazing practices because some of the up-front costs of structures (such as fencing) or the opportunity costs of learning would be lower (Kim, Gillespie, and Paudel, 2008; Lambert, Clark, et al., 2014). A dummy variable indicating if the respondent practiced one or more components of the NRCS definition of prescribed grazing prior to the survey year (UPGR) was included in the adoption/expansion and program participation equations, but omitted from the acreage enrollment equation.

\subsection{Regional Variables}

Regional dummy variables from the USDA's ERS were included in the adoption, participation, and acreage enrollment models (USDA/ERS, 2000). Collectively, the Northern Crescent, Fruitful Rim, Northern Great Plains, and Mississippi 
Portal regions compose the reference category. These regions were combined because the number of respondents reporting from each of these regions was relatively small. Four other regions including the Heartland (HEARTLAND), Prairie Gateway (PRAIRIE), Eastern Uplands (EASTUPL), and the Southern Seaboard $(S O S E A B D)$ are included in each of the three equations. These regional variables control for geographic differences in growing seasons, weather conditions, and input costs.

\section{Results}

Variable means and descriptions are reported in Table 1. Table 2 summarizes the regression results for the acreage enrollment decision process. The model was significant overall, as evidenced by rejection of the null hypothesis that the covariates were jointly insignificant in explaining adoption, participation, and participation intensity (Wald test, $P<0.001$ ). The ADOPT portion of the model correctly classified $79 \%$ of the observations, and the PARTICIPATE model correctly classified $72 \%$ of the observed dependent variables. The correlation between the error terms of PARTICIPATE and ACRES $\left(\rho_{23}\right)$ was statistically significant.

A total of 816 of the 1,153 respondents indicated they would adopt or expand prescribed grazing (Table 1). Of the 1,153 responses used in the analysis, 633 had previously used prescribed grazing. Of these, 540 indicated a willingness to expand their prescribed grazing acres. Only 93 of those already using prescribed grazing indicated they would not consider expanding prescribed grazing even if it was profitable. A total of 520 respondents had not previously used prescribed grazing, and among these, 276 replied they would adopt prescribed grazing, whereas 244 responded they would not be interested in adopting prescribed grazing even if it was profitable.

The correlation between the conditional acres and the actual pasture acres enrolled owned was 0.62 , suggesting that the acreage supply model adequately fit the observed data. The conditional and unconditional means for acres enrolled in the hypothetical program were estimated using the model coefficients at the variable levels of each respondent (equations 13 and 14, respectively). The conditional mean number of pasture acres enrolled into the hypothetical program was 161.51 (conditional upon $A D O P T=1$ and PARTICIPATE $=1$ ), and the unconditional mean was 105.03. The median values were 94.56 (conditional) and 63.26 (unconditional) pasture acres enrolled.

The incentive (INCENTIVE) coefficient was statistically significant and positive in the PARTICIPATE and ACRES equations. For each dollar increase in the incentive, the number of acres that would be enrolled increases by 0.41 , and the probability of participating in the program increases by 0.0012 . Pasture acreage supply was price inelastic with respect to the incentive (supply elasticity 
Table 1. Variable Names, Definitions, and Means

\begin{tabular}{|c|c|c|c|c|}
\hline \multirow[b]{2}{*}{ Variable Name } & \multirow[b]{2}{*}{ Definition } & \multicolumn{3}{|c|}{ Means } \\
\hline & & ACRES & PARTICIPATE & $A D O P T$ \\
\hline \multicolumn{5}{|c|}{ Dependent variables: } \\
\hline $\ln A C R E S$ & $\begin{array}{l}\text { Natural logarithm of acres to be } \\
\text { enrolled in prescribed grazing } \\
\text { program }\end{array}$ & 4.747 & & \\
\hline PARTICIPATE & $\begin{array}{l}\text { Accept incentive level offered }= \\
1 \text {, else } 0\end{array}$ & & 0.710 & \\
\hline$A D O P T$ & $\begin{array}{l}\text { Interested in adopting } \\
\text { prescribed grazing }=1 \text {, else } 0\end{array}$ & & & 0.681 \\
\hline \multicolumn{5}{|c|}{ Explanatory variables: } \\
\hline INCENTIVE & $\begin{array}{l}\text { Annual incentive payment } \\
\text { offered per acre in } \\
\text { hypothetical program, } \$ 10 \text {, } \\
\$ 20, \$ 50, \$ 70 \text {, or } \$ 90\end{array}$ & 51.645 & 50.212 & \\
\hline ACFARM & $\begin{array}{l}\text { Acres owned that are farmed, } \\
\text { acres }\end{array}$ & 565.004 & 532.166 & 486.194 \\
\hline EASTUPL & $\begin{array}{l}\text { Eastern Uplands region }=1 \text {, } \\
\quad \text { else } 0\end{array}$ & 0.235 & 0.214 & 0.233 \\
\hline HEARTLAND & Heartland region $=1$, else 0 & 0.239 & 0.238 & 0.241 \\
\hline PRAIRIE & $\begin{array}{l}\text { Prairie Gateway region }=1, \\
\text { else } 0\end{array}$ & 0.215 & 0.230 & 0.216 \\
\hline SOSEABD & $\begin{array}{l}\text { Southern Seaboard region }=1 \text {, } \\
\quad \text { else } 0\end{array}$ & 0.097 & 0.113 & 0.122 \\
\hline SHRPAST & $\begin{array}{l}\text { Share of acres farmed in } \\
\text { pasture, percent }\end{array}$ & & & 0.528 \\
\hline FERTPAST & $\begin{array}{l}\text { Fertilize pastures as a } \\
\quad \text { management practice }=1 \text {, } \\
\text { else } 0\end{array}$ & & & 0.824 \\
\hline$U P G R$ & $\begin{array}{l}\text { Use of prescribed grazing } \\
\text { practices in } 2012=1 \text {, else } 0\end{array}$ & & 0.644 & 0.524 \\
\hline OTHLIV & $\begin{array}{l}\text { Have livestock other than cattle } \\
\quad=1 \text {, else } 0\end{array}$ & & & 0.265 \\
\hline INC3049K & $\begin{array}{l}2012 \text { taxable household income } \\
\text { of } \$ 30,000 \text { to } \$ 49,000=1 \\
\text { else } 0\end{array}$ & & 0.210 & 0.251 \\
\hline INC5099K & $\begin{array}{l}2012 \text { taxable household income } \\
\text { of } \$ 50,000 \text { to } \$ 99,000=1 \\
\text { else } 0\end{array}$ & & 0.280 & 0.258 \\
\hline INC100149K & $\begin{array}{l}2012 \text { taxable household income } \\
\text { of } \$ 100,000 \text { to } \$ 149,000= \\
1 \text {, else } 0\end{array}$ & & 0.167 & 0.141 \\
\hline INCG150K & $\begin{array}{l}2012 \text { taxable household income } \\
\text { of at least } \$ 150,000=1 \\
\text { else } 0\end{array}$ & & 0.154 & 0.123 \\
\hline$A G E$ & Age of farm operator, years & & & 61.815 \\
\hline SOLE & $\begin{array}{l}\text { Operated as sole proprietorship } \\
\quad=1 \text {, else } 0\end{array}$ & & & 0.817 \\
\hline
\end{tabular}


Table 1. Continued

\begin{tabular}{|c|c|c|c|c|}
\hline \multirow[b]{2}{*}{ Variable Name } & \multirow[b]{2}{*}{ Definition } & \multicolumn{3}{|c|}{ Means } \\
\hline & & ACRES & PARTICIPATE & $A D O P T$ \\
\hline COLLEGE & College graduate $=1$, else 0 & & & 0.583 \\
\hline EXTWK & $\begin{array}{l}\text { Number of extension } \\
\text { workshops attended in } 2012\end{array}$ & & & 0.864 \\
\hline INTERNET & $\begin{array}{l}\text { Uses Internet to make farm } \\
\text { purchases or farm } \\
\text { management decisions }=1 \text {, } \\
\text { else } 0\end{array}$ & & & 0.422 \\
\hline GOVINCENT & $\begin{array}{l}\text { Agrees that government should } \\
\text { offer incentives to adopt } \\
\text { conservation practices }=1 \text {, } \\
\text { else } 0\end{array}$ & & 0.670 & 0.594 \\
\hline WADOPT & $\begin{array}{l}\text { Tends to wait until others have } \\
\text { adopted new technologies to } \\
\text { adopt them }=1 \text {, else } 0\end{array}$ & & & 0.376 \\
\hline STEWARD & $\begin{array}{l}\text { Agrees that role is a steward of } \\
\text { the land and has obligation to } \\
\text { protect it for use by future } \\
\text { generations }=1 \text {, else } 0\end{array}$ & & & 0.931 \\
\hline FAMTKOV & $\begin{array}{l}\text { Family will take over when } \\
\text { ceases farming }=1 \text {, else } 0\end{array}$ & & & 0.616 \\
\hline Number of observations & & 589 & 816 & 1,153 \\
\hline
\end{tabular}

$=0.13$ ), suggesting that farmers were not highly incentive responsive in terms of the acres they would convert.

Although interest in adoption was not influenced by farm size, the likelihood of accepting the incentive and the number of acres that would be converted were. This result suggests that interest in participating in a prescribed grazing management program among farmers is relatively homogeneous across farm sizes. However, farm size did influence the number of acres that would be enrolled among those interested and willing to accept the bid, with each acre farmed (ACFARM) increasing acres enrolled by 0.06 acres.

Geographic differences are evident, with cattle operations in the Eastern Uplands and Southern Seaboard regions less likely to adopt or expand prescribed grazing relative to producers located in the Mississippi Portal, Northern Crescent, Northern Great Plains, and Fruitful Rim farm resource regions (i.e., the reference group). Among producers willing to adopt or expand prescribed grazing and willing to participate in the hypothetical program, farms in the Prairie Gateway (PRAIRIE) or Eastern Uplands (EASTUPL) regions were willing to enroll more acres, 70.89 and 29.90, respectively, compared with farmers located in the reference group region. This result suggests that a prescribed grazing program 
Table 2. Triple Hurdle Regression Estimates and Marginal Effects

\begin{tabular}{|c|c|c|c|c|c|c|c|c|c|}
\hline \multirow{3}{*}{$\frac{\text { Variable }}{\text { INCENTIVE }}$} & \multicolumn{6}{|c|}{ Estimates } & \multicolumn{3}{|c|}{ Marginal Effects } \\
\hline & \multicolumn{2}{|c|}{ ACRES } & \multicolumn{2}{|c|}{ PARTICIPATE } & \multicolumn{2}{|c|}{$A D O P T$} & \multirow{2}{*}{$\begin{array}{r}\text { ACRES } \\
0.409\end{array}$} & \multirow{2}{*}{$\frac{\text { PARTICIPATE }}{0.001}$} & \multirow{2}{*}{$\begin{array}{l}\text { ADOPT } \\
-\end{array}$} \\
\hline & 0.003 & $*$ & 0.004 & $* *$ & - & & & & \\
\hline ACFARM & 0.001 & $* * *$ & 0.000 & $*$ & 0.000 & & 0.064 & $3.75 \mathrm{E}-05$ & $1.86 \mathrm{E}-05$ \\
\hline EASTUPL & 0.278 & $* *$ & 0.208 & & -0.339 & $* *$ & 29.902 & 0.055 & -0.097 \\
\hline HEARTLAND & -0.024 & & 0.020 & & -0.137 & & -3.747 & 0.006 & -0.038 \\
\hline PRAIRIE & 0.777 & $* * *$ & -0.231 & & 0.006 & & 70.887 & -0.068 & 0.002 \\
\hline SOSEABD & -0.059 & & -0.245 & & -0.420 & $* *$ & -21.125 & -0.073 & -0.122 \\
\hline SHRPAST & - & & - & & 0.691 & $* * *$ & 10.025 & - & 0.191 \\
\hline FERTPAST & - & & - & & 0.360 & $* *$ & 5.734 & - & 0.104 \\
\hline$U P G R$ & - & & -0.177 & & 0.562 & $* * *$ & 3.398 & -0.048 & 0.166 \\
\hline OTHLIV & - & & - & & 0.241 & $* *$ & 3.408 & - & 0.066 \\
\hline INC3049K & - & & -0.176 & & -0.085 & & -7.133 & - & -0.024 \\
\hline INC5099K & - & & -0.026 & & 0.077 & & 0.245 & -0.007 & 0.021 \\
\hline INC100149K & - & & -0.054 & & 0.240 & & 1.509 & -0.015 & 0.065 \\
\hline INCG150K & - & & -0.151 & & 0.470 & $* *$ & 0.686 & -0.044 & 0.122 \\
\hline$A G E$ & - & & - & & -0.009 & $* *$ & -0.131 & - & -0.003 \\
\hline SOLE & - & & - & & -0.132 & & -1.873 & - & -0.036 \\
\hline COLLEGE & - & & - & & 0.223 & $* *$ & 3.359 & - & 0.063 \\
\hline EXTWK & - & & - & & 0.068 & $*$ & 1.039 & - & 0.019 \\
\hline INTERNET & - & & - & & 0.364 & $* * *$ & 5.391 & - & 0.102 \\
\hline
\end{tabular}


Table 2. Continued

\begin{tabular}{|c|c|c|c|c|c|c|c|c|c|}
\hline \multirow{3}{*}{$\frac{\text { Variable }}{\text { GOVINCENT }}$} & \multicolumn{6}{|c|}{ Estimates } & \multicolumn{3}{|c|}{ Marginal Effects } \\
\hline & \multicolumn{2}{|c|}{ ACRES } & \multicolumn{2}{|c|}{ PARTICIPATE } & \multicolumn{2}{|c|}{$A D O P T$} & \multirow{2}{*}{$\begin{array}{r}\text { ACRES } \\
18.388\end{array}$} & \multirow{2}{*}{$\begin{array}{c}\text { PARTICIPATE } \\
0.083\end{array}$} & \multirow{2}{*}{$\frac{A D O P T}{0.154}$} \\
\hline & - & & 0.286 & $* *$ & 0.532 & $* * *$ & & & \\
\hline WADOPT & - & & - & & -0.224 & $* *$ & -3.395 & - & -0.063 \\
\hline STEWARD & - & & - & & 0.446 & **** & 7.512 & - & 0.132 \\
\hline FAMTKOV & - & & - & & 0.005 & & 0.072 & - & 0.001 \\
\hline Constant & 4.14 & $* * *$ & 0.585 & $* *$ & -0.712 & $*$ & - & - & - \\
\hline Number of observations & 589 & & 816 & & 1,153 & & & & \\
\hline \multicolumn{10}{|c|}{ Wald test against intercept only (40 df) $396.26^{* * *}$} \\
\hline$\sigma$ & 0.9567 & & & & & & & & \\
\hline$\rho_{12}$ & 0.3722 & & & & & & & & \\
\hline$\rho_{13}$ & -0.5742 & & & & & & & & \\
\hline$\rho_{23}$ & $-0.8061^{* *}$ & & & & & & & & \\
\hline
\end{tabular}

Note: Asterisks indicate the following: ${ }^{*}, P<0.10$; ${ }^{* *}, P<0.05$; and ${ }^{* * *}, P<0.01$. 
would be more widely accepted in some regions than others. Some regions would also see much more acreage enrolled than others.

Prior experience with prescribed grazing (UPGR) and belief that farmers should be stewards of the land (STEWARD) both positively influence interest in adoption. These results suggest that concerns about the effect of their farmland on the environment and prior implementation of environmentally friendly practices positively influence farmer interest in adoption of the prescribed grazing program. Farmers who believed they were stewards of the land (STEWARD) would enroll an additional 7.51 acres. Farmers currently using some form of prescribed grazing (UPGR) would enroll, on average, 3.40 acres more than farmers not practicing prescribed grazing. Beliefs that government incentives are needed to encourage use of environmentally friendly practices (GOVINCENT) also had a positive influence on both adoption and willingness to accept the incentive offered. Farmers who agreed that government payments (GOVINCENT) are important to encourage adoption were willing to enroll an additional 18.39 acres. This acreage increase, when compared with that associated with $S T E W A R D$, potentially reflects the relative importance to farmers of incentives to adopt BMPs.

Education (COLLEGE) and acquisition of information through both the Internet (INTERNET) and extension workshops (EXTWK) all positively influenced adoption. College graduates would enroll an additional 3.39 acres, Internet users would enroll an additional 5.39 acres, and those attending extension workshops would enroll 1.04 acres for each additional workshop attended within the past year.

More risk adverse (WADOPT) and older $(A G E)$ farmers are less willing to adopt. Hence, adopters are more likely to be younger farmers and those who are less likely to take a "wait and see" approach about new technologies. Those taking a "wait and see" approach are projected to adopt 3.40 fewer acres. An additional year in age was associated with a 0.13 -acre decrease in acres enrolled into the program.

A number of other farm characteristics influenced prescribed grazing adoption or expansion. Covariates positively correlated with the adoption/expansion decision included the share of farmland in pasture (SHRPAST), use of fertilizer on pastures as a pasture management practice (FERTPAST), and other livestock $(O T H L I V)$. The finding regarding other livestock was unexpected (the coefficient was hypothesized to be negative). One possible explanation for this result could be that farmers believe prescribed grazing would afford them the opportunity to more intensively graze their cattle, freeing up land for other livestock or enterprises. An additional percent of the operated acres in pasture (SHRPAST) was associated with an additional 10.02 acres enrolled into the hypothetical program, fertilizing pastures was projected to result in an additional 5.73 acres enrolled into the hypothetical program, and other livestock was associated with an additional 3.41 acres. 
Table 3. Expanded Acreage Enrollment Estimates and Carbon Sequestered

\begin{tabular}{lcccc}
\hline \hline & $\begin{array}{c}\text { Estimated Acres } \\
\text { Enrolled } \\
\text { (Thousands) }\end{array}$ & $\begin{array}{c}\text { Standard } \\
\text { Error }\end{array}$ & $\begin{array}{c}\text { Millions MgC } \\
\text { Acre }^{-1} \text { Year } \\
\text { (Thousands) }\end{array}$ & $\begin{array}{c}\text { Standard } \\
\text { Error }\end{array}$ \\
\hline Heartland & 1,288 & 39 & 1,305 & 40 \\
Northern Crescent & 330 & 33 & 335 & 34 \\
Northern Great Plains & 777 & 281 & 524 & 189 \\
Prairie Gateway & 4,548 & 690 & 4,608 & 700 \\
Eastern Uplands & 1,755 & 120 & 1,778 & 121 \\
Southern Seaboard & 1,000 & 450 & 404 & 182 \\
Fruitful Rim & 313 & 86 & 317 & 87 \\
Mississippi Portal & 394 & 22 & 399 & 22 \\
Total & 10,405 & & 9,669 & \\
\hline \hline
\end{tabular}

\section{Conclusions and Discussion}

This study examined how cattle farmers respond east of the 100th meridian to a hypothetical program that would match $75 \%$ of the up-front installation costs and provide an annual payment for a period of 10 years to adopt and continue prescribed grazing. Based on the survey findings, more than $68 \%$ of the respondents expressed a willingness to adopt prescribed grazing. Nearly $71 \%$ of those who were willing to adopt prescribed grazing were also willing to participate in the hypothetical incentive program, with the average annual payment offered at just over $\$ 50$ per acre.

Table 3 shows projections of the number of acres that would be enrolled in the hypothetical program using the results of the econometric model. The projected addition of acres managed using prescribed grazing across the study area, based on the conditional acreage enrollment estimates, is 10.40 million acres (Table 3). By comparison, in 2012 the EQIP practice code 528 grazing land conservation practice (i.e., prescribed grazing) covered about 6.6 million acres (USDA/NRCS, 2013a). In addition, according to the 2012 Census of Agriculture (USDA/NASS, 2014), pasture acreage (cropland or woodland in pasture or permanent pasture) in counties east of the 100th meridian was 103.5 million acres in total, or about $22.7 \%$ of all U.S. pastureland. Program costs from annual payments, assuming 10.40 million added acres at approximately $\$ 50$ per acre would be $\$ 520$ million per year or $\$ 5.2$ billion over the 10 -year period. This cost estimate does not include the up-front $75 \%$ cost share. In 2012, EQIP financial assistance obligations were about $\$ 1$ billion (USDA/NRCS, 2013a). All EQIP funding under the Agricultural Act of 2014, including financial and technical assistance, totals to $\$ 8$ billion between fiscal year (FY) 2014 and FY2018: $\$ 1.35$ billion (FY2014), \$1.6 billion (FY2015), \$1.65 billion (FY2016-FY2017), and \$1.75 billion (FY2018) (Stubbs, 2014). Hence, a $\$ 520$ million per year program would require nearly one-third of all current EQIP funds. 
Prior research suggests that management-intensive grazing can build soil carbon relative to extensive grazing (Conant, Six, and Paustian, 2003; Liebig et al., 2005; Sims and Bradford, 2001). Using Conant, Six, and Paustian's (2003) estimate of 1.01 MT C/acre/year for the Eastern Uplands, Heartland, Southern Seaboard, Northern Crescent, Fruitful Rim, and Mississippi Portal regions; Sims and Bradford's (2001) estimate of 0.67 MT C/acre/year for the Prairie Gateway region; and Liebig et al.'s (2005) estimate of 0.40 MT C/acre/year for the Northern Great Plains, converting these 10.40 million acres (using survey results to distribute these acres among the regions) would sequester an estimated 9.67 million MT C/year. The EPA estimates that the United States emitted 6,526 million MT CO 2 equivalent units in 2012 (EPA, 2014a). Gurian-Sherman (2011) estimated that the livestock sector contributed $2.2 \%$ to total U.S. GHG emissions. Thus, the additional acres enrolled into this hypothetical program could reduce the livestock sector's overall contribution to U.S.-produced GHG by $6.7 \%$. Given the program costs of just over $\$ 520$ million per year for annual incentive payments and projected carbon storage of 9.67 million MT C, the costs from producer incentives per MT of $\mathrm{C}$ are approximately $\$ 53.81$. It is important to note that this value does not capture the additional potential environmental benefits of prescribed grazing such as reduced soil erosion.

Results from this study suggest that an annual incentive program would encourage the adoption and expansion of pasture acres managed using prescribed grazing practices. Findings also suggest that there are significant farm-size effects, with larger farms willing to enroll more acres and more willing to participate in a prescribed grazing program. However, farm size was unassociated with willingness to adopt prescribed grazing or expand current prescribed grazing acres, suggesting that small and large cattle operations that use pasture are equally likely to adopt prescribed grazing.

A profile of farmers who are more likely to adopt include those who are more highly educated, younger, and less risk averse about technology adoption; have more favorable attitudes about government incentives; view themselves as environmental stewards of the land; and have previously used the practice. Education/information variables, such as having a college degree, using the Internet to make farm business decisions, and attending extension workshops, positively influenced willingness to adopt or expand prescribed grazing, suggesting that educational programming may be an effective way to promote prescribed grazing. Farmers who preferred to take a "wait and see" approach to technology adoption were less likely to adopt prescribed grazing. Hence, in common with other BMP adoption studies, producers who tend to be more risk averse about adopting technologies adopt later. Prior adoption of prescribed grazing practices had a positive influence on willingness to adopt or expand prescribed grazing. This suggests that these farmers have had a positive experience with prescribed grazing or, based on their experience with prescribed grazing, believe they could profitably expand it given the incentives offered. 
Attitudes about environmental stewardship of the land play a positive role in adoption, suggesting that farmers do look beyond the profitability of prescribed grazing in making the decision of whether to adopt. The results also suggest that operators who are more favorable toward government incentives encouraging adoption of BMPs will be more likely to adopt or expand prescribed grazing. This could indicate that a program to build carbon storage through grazing practices be well received by farmers who already participate in governmentbased incentive programs for adoption of environmentally friendly practices. Regional differences were also observed, likely reflecting pasture and land parcel adaptability to prescribed grazing (Table 3). For example, the largest positive regional effects on acreage enrollment are found in the Prairie Gateway region. This finding is not surprising, because counties east of the 100th meridian in Texas and Oklahoma are home to $15.9 \%$ of all U.S. pasture acres and $20.8 \%$ of all U.S. beef cattle farms (USDA/NASS, 2014).

A limitation to this study is the geographic detail available to evaluate how site specific characteristics might influence prescribed grazing profitability and/or environmental benefits. Regional variables capture some of these differences, but additional information about pastureland quality and growing conditions would be helpful. Examples of information might include the types of forages that grow in one area versus another, size of pastureland parcels, slope, and other land quality characteristics.

It is important to note that these results represent a snapshot in time that extends out to a period of 10 years. We do not know how many farmers would retain prescribed grazing once the incentive payments expire. The survey questionnaire did ask how many farmers had practiced some type of prescribed grazing practice already, and $53 \%$ said they had. Among those who said they had practiced prescribed grazing, about $15 \%$ received an EQIP payment for it in 2012. This result is suggestive that many farmers would continue using elements of prescribed grazing beyond the 10 years without the EQIP payment. Further research might examine how many of these farmers would continue to practice prescribed grazing beyond the incentive period. Some farmers may continue due to pecuniary benefits accrued from increased forage quantity responses from rotational grazing (Sollenberger et al., 2012) and the fact that the initial upfront investments such as watering facilities and fencing have been made. Other farmers may abandon prescribed grazing on these acres for a variety of reasons, such as retirement or conversion of the land to other uses.

With this understanding of the characteristics affecting adoption/expansion, as well as the influence of cost-share incentive levels, projections of the effects of cost-share and annual incentive rates to obtain desired adoption levels are possible. Further research will extend these findings by extrapolating them across the region east of the 100th meridian to project overall additions to prescribed grazing acreage given varying incentive levels. Acreage enrollment projections can then be used along with environmental measures to formulate regional 
environmental impacts and incentive levels needed to attain environmental targets, such as GHG reduction.

\section{References}

Blamey, R.K., J.W. Bennett, and M.D. Morrison. "Yea-Saying in Contingent Valuation Surveys." Land Economics 75(1999):126-41.

Blaylock, J.R., and W.N. Blisard. "U.S. Cigarette Consumption: The Case of Low-Income Women." American Journal of Agricultural Economics 74,3(August 1992):698-705.

Briske, D.D., J.D. Derner, J.R. Brown, S.D. Fuhlendorf, W.R. Teague, K.M. Havstad, R.L. Gillen, A.J. Ash, and W.D. Willms. "Rotational Grazing on Rangelands: Reconciliation of Perception and Experimental Evidence." Rangeland Ecology \& Management 61(2008):3-17.

Briske, D.D., J.D. Derner, D.G. Milchunas, and K.W. Tate. “An Evidence-Based Assessment of Prescribed Grazing Practices." Conservation Benefits of Rangeland Practices: Assessment, Recommendations, and Knowledge Gaps. D. Briske, ed. Lawrence, KS: Allen Press, 2013.

Cameron, A.C., and P.K. Trivedi. Microeconometrics Using Stata. College Station, TX: Stata Press, 2009.

Conant, R.T., J. Six, and K. Paustian. "Land Use Effects on Soil Carbon Fractions in the Southeastern United States. I. Management-Intensive versus Extensive Grazing.” Biology and Fertility of Soils 38,6(2003):386-92.

Cooper, J.C. "Combining Actual and Contingent Behavior Data to Model Farmer Adoption of Water Quality Protection Practices." Journal of Agricultural and Resource Economics 22(July 1997):30-43.

Cooper, J.C., and G. Signorello. "Farmer Premiums for the Voluntary Adoption of Conservation Plans." Journal of Environmental Planning and Management 51,1(2008):1-14.

Cottle, D.J., J.V. Nolan, and S.G. Wiedermann. "Ruminant Enteric Methane Mitigation: A Review." Animal Production Science 51 (2011):491-514.

Daberkow, S.G., and W.D. McBride. "Farm and Operator Characteristics Affecting the Awareness and Adoption of Precision Agriculture Technologies in the US." Precision Agriculture 4,2(2003):163-77.

Fernandez-Cornejo, J., S. Daberkow, and W.D. McBride. "Decomposing the Size Effect on the Adoption of Innovations: Agrobiotechnology and Precision Agriculture." AgBioForum 4,2(2001):124-36.

Follett, R.F., J.M. Kimble, and R. Lal. "The Potential of U.S. Grazing Lands To Sequester Soil Carbon." The Potential of U.S. Grazing Lands to Sequester Carbon and Mitigate the Greenhouse Effect. Follett, R.F., J.M. Kimble, and R. Lal. (eds.). Washington, DC: Lewis Publishers, 2001.

Foltz, J., and G. Lang. "The Adoption and Impact of Management Intensive Rotational Grazing (MIRG) on Connecticut Dairy Farms.” Renewable Agriculture and Food Systems 20,4(2005):261-66.

Gillespie, J.M., W. Wyatt, B. Venuto, D. Blouin, and R. Boucher. "The Roles of Labor and Profitability in Choosing a Grazing Strategy for Beef Production in the U.S. Gulf Coast Region." Journal of Agricultural and Applied Economics 40,1(April 2008):301-13.

Gurian-Sherman, D. Raising the Steaks: Global Warming and Pasture-Raised Beef Production in the United States. Cambridge, MA: Union of Concerned 
Scientists, February 2011. Internet site: http://www.ucsusa.org/assets/documents/ food_and_agriculture/global-warming-and-beef-production-report.pdf (Accessed November 5, 2013).

Hanson, G.D. “Adoption of Intensive Grazing Systems.” Journal of Extension 33,4(1995).

Jayasinghe-Mudalige, U., and A. Weersink. "Factors Affecting the Adoption of Environmental Management Systems by Crop and Livestock Farms in Canada." Sri Lankan Journal of Agricultural Economics 6,1(2004):25-36.

Kennedy, P. A Guide to Econometrics. 2nd ed. Cambridge, MA: MIT Press, 1985.

Kim, S.-A., J.M. Gillespie, and K.P. Paudel. "Rotational Grazing Adoption in Cattle Production Under a Cost-Share Agreement: Does Uncertainty Have a Role in Conservation Technology Adoption?" Australian Journal of Agricultural and Resource Economics 52(2008):235-52.

Kurkalova, L., C. Kling, and J. Zhao. "Green Subsidies in Agriculture: Estimating the Adoption Costs of Conservation Tillage from Observed Behavior." Canadian Journal of Agricultural Economics 54 (2006):247-67.

Lambert, D.M., C.D. Clark, N. Busko, F.R. Walker, A. Layton, and S. Hawkins. “A Study of Cattle Producer Preferences for Best Management Practices in an East Tennessee Watershed. Journal of Soil and Water Conservation 69,1(2014):41-53.

Lambert, D.M., B.C. English, D.C. Harper, S.L. Larkin, J.A. Larson, D.F Mooney, R.K. Roberts, M. Velandia, and J.M. Reeves. "Adoption and Frequency of Precision Soil Testing in Cotton Production." Journal of Agricultural and Resource Economics 39,1(2014):106-32.

Lambert, D.M., P. Sullivan, R. Claassen, and L. Foreman. "Profiles of US Farm Households Adopting Conservation-Compatible Practices." Land Use Policy 24(2007):7288 .

Lichtenberg, E. "Cost-Responsiveness of Conservation Practice Adoption: A Revealed Preference Approach." Journal of Agricultural and Resource Economics 29(2004):42035.

Lichtenberg, E., and R. Smith-Ramírez. "Slippage in Conservation Cost Sharing." American Journal of Agricultural Economics 93(2011):113-29.

Liebig, M.A., J.A. Morgan, J.D. Reeder, B.H. Ellert, H.T. Gollany, and G.E. Schuman. "Greenhouse Gas Contributions and Mitigation Potential of Agricultural Practices in Northwestern USA and Western Canada." Soil and Tillage Research 83(2005): 25-52.

Lohr, S.L. Sampling: Design and Analysis. Albany, NY: Duxbury Press, 1999.

McFadden, D. "Conditional Logit Analysis of Qualitative Choice Behavior." Frontiers in Econometrics. P. Zarembka, ed. New York: Academic Press, 1974.

Powell, J.R. "Water Quality and Ecological Impacts of Watering Cattle Adjacent to a Small Middle Tennessee Stream.” Master's thesis, University of Tennessee, Knoxville, 1998.

Qualls, D.J., K.L. Jensen, C.D. Clark, B.C. English, J.A. Larson, and S.T. Yen. "Analysis of Factors Affecting Willingness to Produce Switchgrass in the Southeastern United States." Biomass and Bioenergy 39(2012):159-67.

Roberts, R.K., B.C. English, J.A. Larson, R.L. Cochran, W.R. Goodman, S.L. Larkin, M.C. Marra, S.W. Martin, W.D. Shurley, and J.M. Reeves. "Adoption of Site-Specific Information and Variable-Rate Technologies in Cotton Precision Farming." Journal of Agricultural and Applied Economics 36,1(2004):143-58.

Rolfe, J., J. Windle, A. Reeson, and S. Whitten. "Assessing the Incentives Needed to Improve Riparian Management in Grazing Systems: Comparing Experimental Auctions and 
Choice Modelling Approaches.” Paper presented at the 50th Annual Conference of the Australian Agricultural and Resource Economics, Sydney, February 7-10, 2006.

Sims, P.L., and J.A. Bradford. "Carbon Dioxide Fluxes in a Southern Plains Prairie." Agricultural and Forest Meteorology 109(2001):117-34.

Sollenberger, L.E., C.T. Agouridis, E.S. Vanzant, A.J. Franzluebbers, and L.B. Owens. "Prescribed Grazing on Pasturelands." Conservation Outcomes from Pastureland and Hayland Practices: Assessment, Recommendations, and Knowledge Gaps. C.J. Nelson, ed. Lawrence, KS: Allen Press, 2012.

Stubbs, M. Conservation Provisions in the 2014 Farm Bill (P.L. 113-79). Congressional Research Service Report 7-5700 R43504, April 24, 2014.

Thomas, Z.P. "The Effects on Water Quality of Restricting Cattle Access to a Georgia Piedmont Stream.” Master's thesis, University of Georgia, Athens, 2002.

Undersander, D., B. Albert, D. Cosgrove, D. Johnson, and P. Peterson. Pastures for Profit: A Guide to Rotational Grazing. Madison, WI: Cooperative Extension Publications, University of Wisconsin-Extension, Publication A3529, 2002.

U.S. Department of Agriculture, Economic Research Service (USDA/ERS). Farm Resource Regions. Washington, DC: USDA/ERS, Agriculture Information Bulletin No. 760, 2000. Internet site: http://www.ers.usda.gov/media/926929/aib-760_002.pdf (Accessed March 10, 2015).

U.S. Department of Agriculture, National Agricultural Statistics Service (USDA/NASS). 2012 Census of Agriculture. Washington, DC: USDA/NASS, 2014.

U.S. Department of Agriculture, Natural Resource Conservation Service (USDA/NRCS). "Environmental Incentives Program (EQIP)." Internet site: http://www.nrcs.usda.gov/ Internet/NRCS_RCA/reports/fb08_cp_eqip.html (Accessed December 5, 2013a).

U.S. Department of Agriculture, Natural Resource Conservation Service (USDA/NRCS). "EQIP Application Information by State." Internet site: http://www.nrcs.usda.gov/ wps/portal/nrcs/detailfull/national/programs/financial/eqip/? \&cid=nrcs143_008223

(Accessed December 5, 2013b).

U.S. Department of Agriculture, Natural Resource Conservation Service (USDA/NRCS). Fact Sheet-Air Quality and Atmospheric Change: Greenhouse Gases and Animal Operations. Washington, DC: USDA/NRCS, 2008.

U.S. Department of Agriculture Natural Resource Conservation Service (USDA/NRCS). Final Benefit-Cost Analysis for the Environmental Quality Incentives Program (EQIP). Washington, DC: USDA/NRCS, May 24, 2010a.

U.S. Department of Agriculture, Natural Resource Conservation Service (USDA/NRCS). Prescribed Grazing (528) Fact Sheet. Washington, DC: USDA/NRCS, October 15, 2007. Internet site: http://efotg.sc.egov.usda.gov/references/public/TN/ Prescibed_Grazing_\%28528\%29_Fact_Sheet_Final_2007.pdf (Accessed February 21, 2015).

U.S. Department of Agriculture, Natural Resource Conservation Service (USDA/NRCS). Prescribed Grazing - Practice Introduction. Washington, DC: USDA/NRCS, 2010b. Internet site: http://www.nrcs.usda.gov/Internet/FSE_DOCUMENTS/stelprdb1045100.pdf (Accessed January 22, 2015).

U.S. Environmental Protection Agency (EPA). "Climate Change Indicators in the United States.” Internet site: http:/www.epa.gov/climatechange/science/ indicators/ghg/us-ghg-emissions.html (Accessed September 25, 2014a).

U.S. Environmental Protection Agency (EPA). Inventory of U.S. Greenhouse Gas Emissions and Sinks, 1990-2012. Washington, DC: EPA, No. 430-R-14-003, 2014b. 
Walton, J.C., D.M. Lambert, R.K. Roberts, J.A. Larson, B.C. English, S.L. Larkin, S.W. Martin, M.C. Marra, K.W. Paxton, and J.M. Reeves. "Adoption and Abandonment of Precision Soil Sampling in Cotton Production." Journal of Agricultural and Resource Economics 33,3(2008):428-48.

Walton, J.C., J.A. Larson, R.K. Roberts, D.M. Lambert, B.C. English, S.L. Larkin, M.C. Marra, S.W. Martin, K.W. Paxton, and J.M. Reeves. "Factors Influencing Farmer Adoption of Portable Computers for Site-Specific Management: A Case Study for Cotton Production." Journal of Agricultural and Applied Economics 42,2(2010):193-209.

Watcharaanantapong, P., R.K. Roberts, D.M. Lambert, J.A. Larson, M. Velandia, B.C. English, R.M. Rejesus, and C. Wang. "Timing of Precision Agriculture Technology Adoption in US Cotton Production." Journal of Precision Agriculture 15(2014):427-46.

Yen, S.T. "A Multivariate Sample-Selection Model: Estimating Cigarette and Alcohol Demands with Zero Observations." American Journal of Agricultural Economics 87,2(May 2005):453-66.

Yen, S.T., and J. Rosinski. "On the Marginal Effects of Variables in the Log-Transformed Sample Selection Models.” Economics Letters 100 (2008):4-8. 